\title{
IMPROVING STUDENTS' WRITING COHERENCE THROUGH GRAPHIC ORGANIZERS
}

\author{
Inayatun Nafiah, Gunarso Susilohadi, Hefy Sulistyawati
}

\author{
English Education Department \\ Teacher Training and Education Faculty \\ Sebelas Maret University of Surakarta
}

E-mail: inaynafiah@gmail.com

\begin{abstract}
This research is aimed at finding out: 1) To what extent graphic organizers can improve students' writing coherence; 2) How graphic organizers can be implemented effectively in improving students' writing coherence. The research method used in this study is classroom action research. The subject of the research was the students of class VIIIB of a state Junior High School, Kebumen which consist of 32 students. In this research, the collected data were analyzed using a qualitative and quantitative technique. The result of the study shows that the students' mean score of writing coherence on pre-test is 56.35, then it improves in post-test 1 to 70.45 and 79.4 in post-test 2 . Moreover, the result of the study also shows that graphic organizers can be implemented effectively if the teacher: (1) gives clear explanation and examples of graphic organizers; (2) guides and monitors the students during the process of writing; (3) provides exercise of grammar; and (4) keeps the students motivated in writing. Considering the result of the study, the researcher suggests that an English teacher had better implement graphic organizers in teaching writing in order to help the students improving their writing coherence.
\end{abstract}

Keywords: graphic organizer, graphic organizers, writing, writing coherence, classroom action research

\section{INTRODUCTION}

Writing is one of the important skills that will help students to communicate with other people around the world. The increasing use of the internet makes a good opportunity for Indonesian students to do communication with English native speakers. Through the growing use of English, nowadays, schools use English in the classroom teaching-learning process. Along with that reason, the writing ability is very needed by the students. However, writing is considered as the most difficult skill among the four basic language skill.

According to Harris (in Hughes, 2003, p.101), there are five aspects of writing should be mastered by the students to be able to write well. They are grammar vocabulary, mechanics, fluency, and organization. Fluency and organization in writing are related to coherence. By mastering them, students are expected to be able to make paragraphs in the text logically connected. Moreover, Nunan (2005, p.102) states there are five steps in teaching writing should be done by the teacher. They are prewriting, writing, revising, editing, and publishing. By following the process of writing students are expected to be able to write text in many varieties of genres such as recount and narrative.

In addition, based on the syllabus for the eighth-grade students of junior high school there are standard competence and 
basic competence should be achieved by the students. The standard competence should be achieved by students is students should be ably expressing the meaning of written functional text and a short essay in recount and narrative to interact with surroundings. However, the basic competence is students should be able expressing meaning and rhetorical step in short essay by using the right mechanical writing to interact with the environment around in form of a recount and narrative text. Based on the standard and basic competence, at the end of the teachinglearning writing, students should be able (1) mentioning social function of a recount and narrative text; (2) mentioning the generic structure of recount and narrative text; and (3) mentioning language features of a recount and narrative text.

Meanwhile, there were still many problems faced by the students in their writing coherence. The students were still lack of vocabularies. The students were difficult to use correct grammar and vocabulary in their writing and the students were also still difficult to find ideas and put them in good paragraphs.

However, students are expected to write paragraph coherently. According to Hackers and Sommers (2012, p61), there are five aspects should be mastered by the students in order to write coherently. They are describing events in chronological order, repeating keywords, creating parallel structure, being consistent in a point of view and verb tense, and using transition.

The researcher found the media which are appropriate to solve the problems and to improve the writing coherence. It is graphic organizer. Graphic organizers are a visual framework for assisting students to formulate ideas and organize their ideas into a good writing. Baxendell (2003, p.48) stated that the primary purpose of using graphic organizer in writing is to make abstract concept and relationship clear. The use of graphic organizer is to help students focus on main idea. Baxendell also stated that one method for assuring coherence is to clearly label the ideas or concepts on graphic organizers.

Based on the discussion above, the problem of the research are:

1. To what extent do Graphic Organizers improve the students' writing coherence?

2. How can Graphic Organizers be implemented effectively in improving students' writing coherence?

Moreover, the objectives of the research are to analyze to what extent Graphic Organizers improve students' writing coherence and to describe how Graphic Organizers can be implemented effectively in improving students' writing coherence.

\section{LITERATURE REVIEW \\ Definition of writing}

Brown (2004: 218) states that writing is primarily a convention for recording speech and for reinforcing grammatical and lexical features of language. Writing is a nonlinear, explanatory, and generative process whereby writers discover and reformulate their ideas as they attempt to approximate meaning (Zamel in Hyland, 2009: 20).

Hacker (2009, p.3) states that writing is a process figuring out what you think. In writing, a writer will do steps from planning to drafting to revising. In line with Hacker, Oshima and Hogue (2007, p.15) explained that writing is an ongoing creative act. The process of writing has four steps; create ideas, organize ideas, write a rough draft, and polish the rough draft by editing and making revisions.

Moreover, Sokolik (in Nunan, 2005, p.98) states that writing is a combination of process and product. The process refers to the act of gathering ideas and working with them 
until they are presented in a product that is polished and comprehensible to the readers.

\section{Aspect of writing}

To deliver the information well, a writing product should be well-developed. According to Hughes (2003, pp.101-102), there are five aspects of a good writing. They are grammar, vocabulary, mechanics, and fluency.

From all five aspects, fluency and organization in writing should be learned well. Fluency and organization in writing are related to coherence. Students should be able to make paragraphs in the text logically connected.

\section{Coherence in writing}

Coherence in a text is important because it will help the readers to easily understand the information the text. A text is called coherent when the paragraphs fit together in a natural way. As Hacker and Sommers (2012, p.61) said, when sentences and paragraphs flow from one another without discernible bumps, gaps, or shifts, they are said to be coherent. There are several aspects of coherence. They are the ideas are linked clearly, repeating the keywords, creating parallel structures, being consistent in point of view and verb tense, providing transitions.

\section{Based on American University} Journal, there are several factors of coherence. They are chronological sequence, modified chronology, spatial position of different objects, 'conversation' between different experts, and logical form of argument.

In conclusion, there are five aspects of writing coherence that will be used in assessing writing coherence. They are describing events in chronological order, repeating key words, creating parallel structure, being consistent in point of view, verb tense, and number, and using transition.

\section{Definition of graphic organizers}

Bromley, Irwin-DeVitis, and Modlo (1999, p.6) defined graphic organizer as a visual representation of knowledge that structures information by arranging important aspects of a concept or topic into a pattern using labels.

McKnight (2010, p.1) stated Graphic organizers are important and effective pedagogical tools for organizing content and ideas and facilitating learners' comprehension of newly acquired information. Graphic organizers support students by making them to see connection and relationship among facts, information, and terms.

Also, Goodnough and Robin (2002, p20) described graphic organizers as a visual representation of knowledge that goes by variety names such as semantic maps, webs, and Venn diagrams. They help students construct understanding through exploration of a relationship between concepts. However, Clements-Davis \& Ley (in Mede, 2009, p.322) stated that graphic organizers may not be effective learning tools without teacher instruction on how to use them.

\section{RESEARCH METHOD}

The research method used in this study is a classroom action research. Pelton (2010, p.3) states action research, in the school setting, is a systematic approach to improve teaching practice. The methods of action research are designed to answer the most basic question of education: How well are my students learning what I am teaching?

Moreover, Costello (2003, p.5) states that action research is referred to variously as a term, process, enquiry, approach flexible spiral process and as cyclic. It has practical, 
problem-solving emphasis and aims to improve education practice.

According to Kemmis and McTaggart (in Burns, 2010, p.7), action research typically involves four broad phases in a cycle of research. The four steps of action research are planning, action, observation, and reflection. In planning, the researcher developed action plan. Second, in action stage, the researcher put the action plan in the teaching situation. Third, in the observation stage, the researcher observed the effect of the action and collecting it as a data. Last, in the reflection stage, the researcher the researcher reflected on, evaluated, and described the effect of the action in order to see if there any improvement of the students.

This action research was held in the eighth grade of a state Junior High School, Kebumen. The subject of the research is the eighth-grade students. The class consists of 32 students, 16 females and 16 males. The research is conducted through teaching and learning process in the eighth-grade students of class VIII B from November 2016 to June 2017.

The data in this research are collected through interview, observation, and test. Before the research, the researcher interviewed the English teacher and the students. The researcher also interviewed the students at the end of each cycle related to the implementation of graphic organizer. Moreover, the researcher also interviewed the English teacher related to the teaching and learning process using graphic organizers. The researcher conducted an observation in the pre-research and during the implementation of the action. In the preresearch, the researcher observed the way the teacher taught writing and the students' activities during the writing classroom. Last, the researcher gave a pre-test and post-test to find out students' writing coherence before and after the implementation of graphic organizers. The researcher also took photographs and used them for documentation of the teaching and learning process.

In this research, the collected data were analyzed using qualitative and quantitative technique. The results from interviews and observation were analyzed by using qualitative approach. Meanwhile, the data from the test result were analyzed by using quantitative approach. The techniques used to analyze the qualitative data of this Classroom Action Research (CAR) are assembling the data, coding the data, comparing the data, building interpretations, and reporting the outcomes. Burns (2010, pp.104-105). Moreover for the quantitative data were analyzed using formula to find out the mean of score in pre-test and post-test.

\section{RESEARCH FINDINGS AND DISCUSSION}

The implementation of graphic organizer in teaching and learning writing influence students' writing coherence and the classroom situation. Before the action, the score of the students' writing coherence was very low. The result of the pre-test proved how the students had many difficulties in their writing. It shows that only a few students could reach the minimum standard score (KKM). The minimum standard score was 70 . The highest score by the student was 70 , the lowest score was 34 , and the mean score of the pre-test result was 56.35. Moreover, the classroom activities before the research were monotonous. The activity to improve students' English skill was limited, the class situation was boring, the students' participation in the lesson was low, and the students did not pay attention to the teacher.

In the cycle 1, the score of the post test showed that there is improvement in students' writing coherence. Before the research, the highest score was 70 , the lowest 
score was 34 , and the mean score was 56.35 . Meanwhile, after the implementation of graphic organizer in teaching and learning writing, the students' writing coherence was improving. The highest score of post-test 1 was 81 , the lowest was 53 , and the mean score was 70.45 . In addition, there were also improvements in classroom situation. The students seemed more enthusiastic in following the English lesson. Some students were also more active during the teaching and learning process.

In cycle 2, there was more improvement in students' writing coherence. The highest score achieved by the students was 84 and the lowest score was 74 . The mean score was improved to 79.4. There were also improvements in the classroom situation after cycle 2 . The students do every step of writing process taught be the researcher, the students did writing with their best effort, and the students had more motivation to practice writing.

Based on the result in pre-research, post-test 1 , and post-test 2 , there were improvements in every indicator of the students' writing coherence. First, in arranging paragraphs in chronological order, the mean score of the students before the research was 18.59. However, after the implementation of the graphic organizer, the mean score of this indicator was improved to 22.72 in post-test 1 and became 27.03 in posttest 2 .
Second, in the indicator of repeating key words or phrases, the mean score in the pre-research was 11.65. The mean score in post-test 1 improved to 13.93 and it even more improved in the post-test 2 to 17.93 .

Third, in the indicator of creating parallel structure, in the pre-research test, the mean score of the test was 11.13 . Then, it improved in the post-test 1 and even got a higher mean score in post-test 2 . The mean score of this indicator in post-test 1 was 12.96 and became 17.43 in post-test 2 .

Fourth, in the indicator of consistent in point of view, verb tense, and number, the mean score of this indicator in the preresearch test was 12.90. But after the action of the research, they achieved so much improvement. The mean score of this indicator improved in both post-test 1 and post-test 2 . The mean score of post-test 1 was 17.10 and 21.76 in post-test 2.

Last, in the indicator of using transition, the mean score of this indicator was 2.1. However, there was an improvement in post-test 1 and post-test 2 . The mean score of post-test 1 was 3.7.

Moreover, the mean score of post-test 2 improved to 4. Generally, the improvements of each indicator of the students' writing coherence during the implementation of Graphic Organizer could be seen in the following graph 
Graph 1. The Mean Score of the Students' Writing Coherence

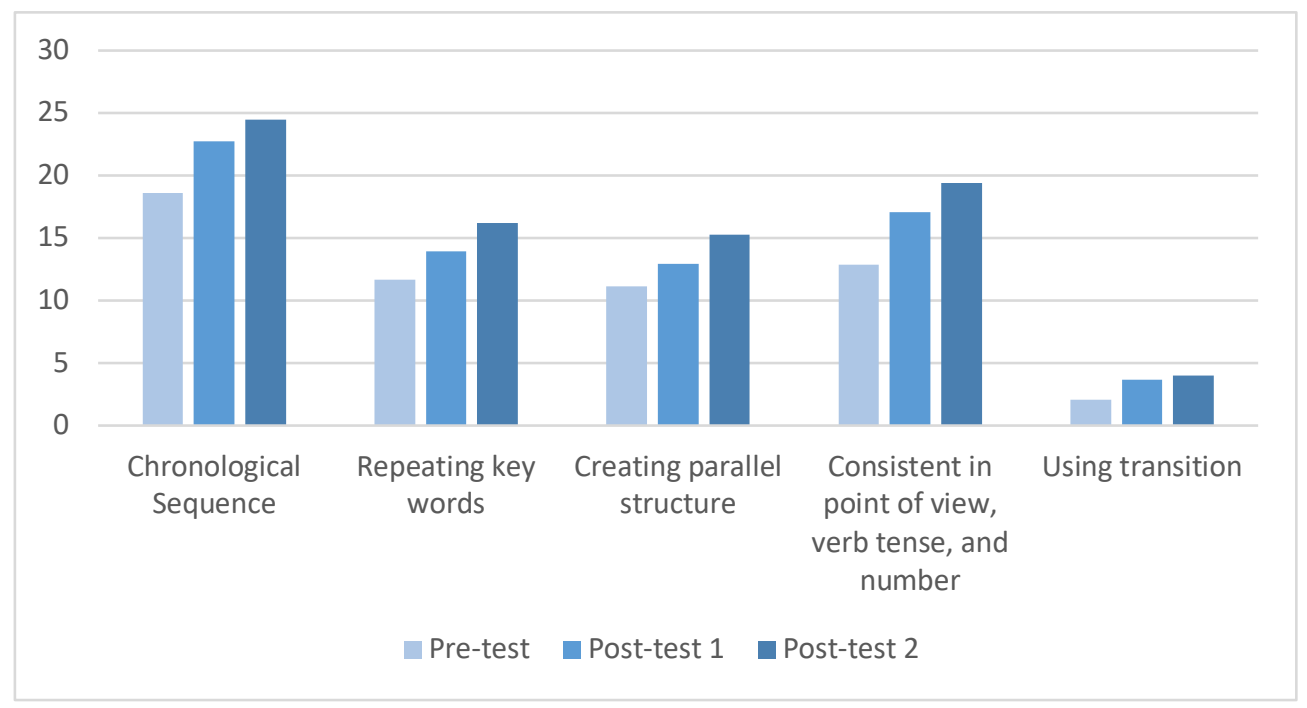

Some conditions have to be fulfilled for the effective implementation of graphic organizer. They are as follows:

1. Giving clear explanation and examples of graphic organizers

McKnight (2010, p.2) gave advice that it is critical to model the graphic organizers when teacher presents it to the class. Teacher needs to show the students how she/he, as a learner, use this organizer to understand material. Because at the beginning of the lesson, the students might not know what graphic organizer is, how to use it, and how it would help their writing. In order to make the media work, teacher should explain first about graphic organizer and makes the students know the essential of graphic organizers. The teacher should explain what graphic organizers are, the benefits of it, and the process of writing by using graphic organizer.

It is also needed to show some examples of graphic organizers to the students. It will enlarge the students' knowledge and imagination about graphic organizers.

2. Guiding and monitoring the students during the process of writing

In the process of teaching writing using a graphic organizer, a teacher needs to guide students in filling up each part of the graphic organizer. Hence, writing using a graphic organizer is categorized into guided writing. Reid (1993, p.25) stated that there is one step in guided writing where the teacher needs to help students build up an outline or list of key expressions on the board as a basis for students' writing. It means the teacher needs to guide and monitor the students during the writing process. The teacher may hold a discussion so the students get ideas about what to write.

Moreover, to make a final product of writing need some stages to be passed. From pre-writing, writing, and revising. Graphic Organizers provide steps that lead the students to do the process of writing. The teacher needs to guide students during the process of writing. The teacher cannot just briefly teach the students how to use graphic organizers. Using graphic 
organizers make the students develop paragraph sentences by sentences. Forming the sentences into a paragraph is the next big step to do by the students. Although the students already had idea or outlines about what to write, they might be still confused about how to make it becomes good paragraphs.

The teacher must not neglect all these processes and only assess students' written product. If the teacher neglects the students during the writing process, there might be a high possibility that the students will cheat or just copy another writing text. More of that, the teacher should make sure that the students comprehend each step of using graphic organizers. By comprehending the step of writing using graphic organizer will also lead the students to get a good score in their writing.

\section{Providing exercise of grammar}

According to Reid (1993, p.25), one of step in teaching guided writing is language based exercise. Teacher gives a series of exercises which focus on vocabulary building and sentence structure knowledge related to text. Here, Grammar is one of the problem faced by students in their writing. In order to make students easily build their sentences, it will be good if the teacher give them exercise related to grammar before they write. The exercise of the grammar should be related to the genre of the text they will write.

4. Keeping the students motivated in writing Miller and Lee (2000, p.8) stated that teacher needs to help students feel comfortable as writers so they will begin to choose to write on their own, without external prompts or assignments. Doing all the process of writing using graphic organizer like pre-writing, writing, and reviewing might be a very different activities for the students. The teacher should always motivate the students to be able finish their writing. The students must know that each step of writing will make their text better and it will be easier to make paragraph of their text. Moreover Irwin-DeVitis, and Modlo (1999, p.108) stated that in the process of teaching writing by using graphic organizer, teacher should encourage students to use the graphic organizer as an outline of their paper. Hence, students will be easy in following every steps of writing process.

\section{IMPLICATIONS}

Based on the research findings, Graphic Organizers are effective media to teach writing especially in improving students' writing coherence. The result of the research has proven that the mean score of the students' writing coherence has improved. As the media used in the writing process, Graphic Organizers can help the students produce their writing in proper sequences. Being able to write paragraphs in proper order is one of the categories of writing coherence. Graphic Organizers contain diagrams or columns that help the students to make outlines and concepts concerning the topic of their writing. Then, the students write those outlines in paragraphs based on the graphic they have made. Hence, Graphic Organizers help the students easily write their paragraphs because they already made the outlines before. The students do not have to worry about forgetting their ideas because they can look for it in the graphic organizer. It will make students' writing flow in proper order

The other categories of writing coherence - improvement in repeating key words or phrases, improvement in creating parallel structures, improvement in being 
consistent of point of view, verb tense, and number, and improvement in using transition word or phrases - can be achieved by the students. Those categories in coherence are related to mechanic in writing categories.

In writing by using graphic organizers, students have to differentiate the main idea and the supporting details. The step in adding the supporting details will make students finding more vocabularies that will help them improve their skill in building sentences. The step in graphic organizers where students need to arrange sentences they already wrote in the graphic will help the students more aware of their consistency in using point of view, verb tenses, number, and even appropriate transition they should use.

\section{CONCLUSION AND SUGGESTION}

This research is aimed at finding out the effective way of implementing Graphic Organizers to improve students' writing coherence and to know to what extent Graphic Organizers can improve the students' writing coherence.

Based on the research, by implementing Graphic Organizers in writing class, the students' writing score has improved. It can be seen from the result of pre-test and post-test. The mean score had always improved from pre-research to posttest 1 and from post-test 1 to post-test 2 .

Moreover, there are some conditions have to be fulfilled for the effective implementation of a graphic organizer. They are: 1) Giving clear explanation and examples of Graphic Organizers; 2) Guiding and monitoring the students during the process of writing; 3) Providing exercise of grammar, and 4) Keeping the students motivated in writing

Based on the research findings, the researcher would like to give some suggestion for English teachers, and students. This research has revealed that the use of
Graphic Organizers gave significant impact to students' writing coherence. Therefore, it is suggested for English teachers to use this media in teaching and learning writing, especially when they want to improve some aspects of writing like the coherence in students writing. English teachers can develop the activities in this media. Moreover, the English teacher can design their own concept in implementing graphic organizers. English teacher also has to make sure that the class condition, especially in teaching writing, is interesting rather than stressful and boring. Graphic organizers are one of the media that is good for improving the class situation. It helps students more passionate and active in their writing.

Moreover for the students, the students should have high learning motivation to make them feel ready and comfortable in joining English lesson. They must study hard and motivate themselves. Although writing is challenging activities in English subject matter, students should have high motivation to learn it, not only in school but at home too. This media can help students practice more and more in their writing. Graphic organizers facilitate students with activities that can be focused to improve their coherence in writing, so that they can produce better writing product. Graphic organizers also lead students to their creativity in writing. The students are also suggested to be more active in teaching and learning process for the sake of improving their writing coherence.

\section{BIBLIOGRAPHY}

Baxendell, B.W. (2003). Consistent, Coherent, Creative, The 3 C's of Graphic Organizers. Teaching Exceptional Children. Page 46 - 53.

Bromley, K., Irwin-DeVitis, L., \& Modlo, M. (1999). 50 Graphic Organizers for 
Reading, Writing, and More. New York: Scholastic Professional Books.

Brown, H.D. (2004). Language Assessment: Principle and Classroom Practices. New York: Pearson Education, Inc.

Burns. A. (2010). Doing Action Research in English Language Teaching: A Guide for Practitioners. New York: Taylor \& Francis.

Castello, P.J.M. (2003). Action Research. London: Biddles Ltd.

Goodnough, K \& Robin, L. (2002). Mind mapping: A graphic organizer for pedagogical toolbox. Science Scope, Agricultural and Environmental Science Database. Page 20 - 24.

Hacker, D. (2009). A Writer's Reference. Boston: Bedford/St. Martin's.

Hacker, D. \& Sommers, N. (2012). Rules for Writers. Boston: Bedford/St. Martin's.

Hughes, A. (2003). Testing for Language Teachers, Second Edition. Cambridge: Cambridge University Press.

Hyland, K. (2009). Teaching and Researching Writing. London: Pearson Education, Inc.

Irwin-DeVitis, and Modlo (1999). 50 GraphicOrganizers for Reading, Writing \& More. New York: Scholastic Professional Books.

McKnight, K. S. (2010). The Teacher's Big Book of Graphic Organizers: 100
Reproducible Organizers that Help Kids with Reading, Writing, and the Content Areas. San Francisco: JosseyBass Book.

Mede, E. (2010). The Effect of Instruction of Graphic Organizers in Terms of Students' Attitudes towards Reading in English. Procesia Social and Behavioral Sciences 2. Page 322 - 325.

Miller and Lee (2000). The Big Book of Ready-to-Go Writing Lessons, 50 Enganging Activities with Graphic Organizer that Teach Kids How to Tell a Story, Convey Information, Describe, Persuade, and More. New York: Scholastic Professional Books .

Nunan, D. (2003). Practical English Language Teaching, First Edition. New York: McGraw-Hill ESL/ELT.

Nunan, D. (2005). Practical English Language Teaching: Young Learners. New York: McGraw-Hill ESL/ELT.

Oshima, A \& Hogue, A. (2007). Introduction to Academic Writing. New York: Pearson Education, Inc.

Paragraph Unity and Coherence. (2009). American University Journal.

Pelton, R.P. (2010). Action Research for Teacher Candidates: Using Classsroom data to Enhance Instruction. Maryland: Rowman \& Littlefield Education.

Reid, Joy M. (1993). Teaching ESL Writing. New Jersey: Prentice Hall Regents. 